\title{
Theistic Reflections on Counseling and Psychotherapy
}

\author{
Muhammet Cevat Acar ${ }^{1}$ \\ Mardin Artuklu University
}

"A Spiritual Strategy for Counseling and Psychotherapy" P. Scott Richards and Allen E. Bergin, Washington DC, 2011, APA, 422 p.

Although religion and science share many similar goals, as evidenced by several philosophical and theoretical studies, there are also many points where they diverge. In this context, ensuring individuals' psychological well-being is the purpose of both religion and science. However, the effort of psychology to become a scientific field has blocked the use of religious material for the purpose of protecting and improving psychological health for a long time. In this point, P. Scott Richards and Allen E. Bergin's book, A Spiritual Strategy for Counseling and Psychotherapy, shows that it is possible to integrate these two fields to serve a common purpose by expressing in scientific terms the contributions that monotheistic religions may provide for individuals' psychological well-being. The main purpose of the book is to describe the concepts and interventions that will help mental health professionals implement theistic psychotherapy (p. 11).

Having received his $\mathrm{PhD}$ in counseling psychology, P. Scott Richards has produced several publications on spirituality and psychotherapy and is currently a licensed psychologist and a full professor of Brigham Young University as well as the Director of Research for the Center for Change. Allen E. Bergin received his PhD in Clinical Psychology from Stanford University and has been a sounding voice about integrating spiritual themes into psychological theory, research, practice, and education.

The first part of the 12 chapter book emphasizes the need for a theistic perspective that can be used in the counseling and psychotherapy process. In the second and third chapters, a historical view of the relationship between religion and science is conveyed and the effects of change movements and positive psychology at the beginning of the

\footnotetext{
1 Dr. Muhammet Cevat ACAR, Department of Psychology, Mardin Artuklu University, Mardin, Turkey. Email: mcacar47@gmail.com Citation: Acar, M. C. (2018). Theistic reflections on counseling and psychotherapy [A Spiritual Strategy for Counseling and Psychotherapy book review P. S. Richards \& A. E. Bergin]. Spiritual Psychology and Counseling, 3, 223-225. http://dx.doi.org/10.12738/spc.2018.3.2.0043R
} 
twentieth and early twenty-first centuries are discussed. In the fourth and fifth chapters, the theological, philosophical, theoretical, and empirical foundations of the theistic psychotherapy are discussed. The next five sections deal with the implementation process of the theistic psychotherapy. These chapters describes how to use the theistic perspective in psychotherapy, especially religious and spiritual assessment and religious and spiritual practices and interventions, and end with examples from the spiritual and religious psychotherapy interventions used today. The last two chapters consist of research models related to theistic psychotherapy and predictions about the future state of this field.

Modern psychology has an ambitious aim, namely recognizing and explaining the human being. In doing so, however, it overlooks the divine, love, inner, and spiritual dimensions of man. This is a necessary consequence due to the fact that psychology is a product of the modern scientific paradigm. Psychology has ignored the direction of human love for the sake of staying true to the scientific method. This situation has caused the alienation of the person, who has been reduced to a mere object of research (Gültekin, 2008, p. 14-15). This perspective reflected in the psychological help process has begun to change with the establishment of Society for the Psychology of Religion and Spirituality (Division 36) of the American Psychological Association (APA), and this change has also manifested itself in the field of psychological help. The publication of this work by the APA is one of the clearest indicators of the convergence between mental health field and religious subjects.

Richards and Bergin express that man cannot be reduced to only physiology, biology, and environment, but that man is an infinite soul created by God. This reflects that man's fundamental reality is his transcendent dimension (p. 103). Indeed, the authors' inclusion of the quote by French philosopher Teilhard deChardin where he states, "We are not human beings having a spiritual experience; We are spiritual beings having a human experience," in the book's introduction is the most veiled expression of this reality.

It is emphasized in the book that the traditional psychotherapy approaches, since they are centered on the naturalistic and atheistic worldview, cannot appreciate the complexity and mystery of life and the universe (p. 19). Nevertheless, it is an undeniable fact that contemporary scientific views and science philosophy and psychology are more compatible with the theistic philosophical assumptions than in the previous decades (p. 24). Richards and Bergin acknowledge that theistic psychotherapy has not yet reached an equal place with the mainstream secular therapy traditions. However, the attention given in textbooks, journals, and graduate training programs indicates that theistic clients from many cultures will readily accept it (p. 153).

Some approaches to integrating religion and spirituality into the counseling process try to integrate all spiritual traditions and experiences (Sperry and Shafranske, 2009), some approaches specifically attempt to integrate a single religious or spiritual approach 
with counseling (Dharamsi and Maynard, 2013 Hawkins, Tan and Turk, 1999). This book presents the basic assumptions and techniques of the theistic model that aims to integrate all theistic religions into the psychological help process. The theistic model is a comprehensive orientation that includes a theistic conceptual framework, a body of religious and spiritual therapeutic interventions, and guidelines for implementing theistic perspectives and interventions. The foundational assumptions of this model are that 'God exists, that human beings are the creations of God, and that there are unseen spiritual processes by which the link between God and humanity is maintained' (p. 13).

The authors argue that the approach they developed can be used for all theistic religions, although the theistic religions have clear commonalities, the different subgroups within these religions must have different religious practices, making it difficult to open a universal theistic view. Culturally sensitive psychological counseling services are at the forefront today. Given this situation, it is difficult to establish a general therapeutic approach to all theistic religions or a single divine religion. However, this book is essential for counselors working in the field of psychological counseling and psychotherapy and have a theistic world view. The negative attitudes toward religion of professionals working in the psychology field in Turkey country is quite evident. Published by the APA and advocating that religion is an indispensable source for clients during recovery, this work offers a new perspective to the professionals working in Turkey.

In conclusion, the authors posit that exercising faith in God and having spiritual experiences help humans to gain expanded, deeper, and spiritually inspired meanings and perspectives of themselves, others, and the universe, thus enabling greater goodness and morality (p. 105). Based on this assumption, they explain (a) the principles of the therapist's goals, (b) the role of the therapist in the therapy process, (c) the role of the spiritual interventions in the therapy process, (d) the role of the client in the therapy process, and (e) the basic principles of the theoretical approach in the context of the relationship (p. 182).

\section{References}

Dharamsi, S. \& Maynard, A. (2013). Islamic-based interventions. In Sameera Ahmed and Mona M. Amer (Eds.), Counseling Muslims: Handbook of mental health issues and interventions (pp. 135-160). New York, USA: Routledge.

Gültekin, M. (2008). Psikolojik tehlike: Modern psikoloji mağduru olmayın. İstanbul: Nesil Yayınları.

Hawkins, R. S., Tan, S. Y. \& Turk, A. A. (1999). Secular versus Christian inpatient cognitivebehavioral therapy programs: Impact on depression and spiritual well-being. Journal of Psychology and Theology, 27(4), 309-318.

Sperry, L. \& Shafranske, E. P. (2009). Spiritually oriented psychotherapy. Washington, DC: American Psychological Association. 